\title{
薬剤反応性に影響を及ぼす遺伝子多型の簡易迅速検出法の開発とその臨床応用
}

\author{
平塚真弘
}

\section{Development of Simplified and Rapid Detection Assay for Genetic Polymorphisms Influencing Drug Response and Its Clinical Applications}

\author{
Masahiro HiRATSUKA \\ Department of Pharmaceutical Sciences, Tohoku University Hospital, 1-1 Seiryo-machi, \\ Aoba-ku, Sendai 980-8574, Japan
}

(Received March 13, 2002)

\begin{abstract}
Clinically important genetic polymorphisms influencing drug metabolism and drug response have typically been discovered on the basis of phenotypic differences among individuals from different populations. Routine genotyping before drug therapy may enable the identification of responders, nonresponders, or patients at increased risk of toxicity. Automated, high-throughput detecting methods for single-nucleotide polymorphisms (SNPs) are highly desirable in many clinical laboratories. The aim of this study is to develop a high-throughput genotyping method for detecting SNPs influencing drug response in the Japanese population. We have developed three real-time PCR assays for detecting SNPs in the human drug-metabolizing enzymes and drug targets. The assay for simultaneously detecting CYP2A6, CYP2B6, CYP2C9, CYP2C18, CYP2C19, CYP2D6, CYP2E1, CYP3A5, NAT2, TPMT, DPYD, UGT1A1, ALDH2, ADH2, MDR1, CETP, DCP-1, ADRB2, HTR2A, INPP1, SDF1, and mitochondrial DNA polymorphisms takes less than $1.5 \mathrm{~h}$. With the clinical application of NAT2 genotyping, we found statistically significant difference between the incidence of adverse drug reactions (ADRs) and the NAT2 genotype. The incidence of the ADRs was significantly higher in the slow type than the in other two types, as 5 of the 6 patients were of the slowtype, and the other was the intermediatetype, while no patients of the rapidtype has developed any ADRs.
\end{abstract}

Key words_ _ single-nucleotide polymorphism; pharmacogenetics; real-time PCR

\section{はじめに}

薬の効き具合や副作用の出やすさには著しい個人 差が存在する. 近年, ヒトゲノム・遺伝子解析研究 の伸展により，このような薬剤反応性における個人 差の原因の 1 つとして遺伝子の多型性が注目されて いる。現在，薬物代謝酵素であるチトクローム P450（CYP）やCYP 以外の薬物代謝酵素の一塩基 多型 (Single Nucleotide Polymorphism; SNP) 解析 が加速度的に進展しており, 遺伝子多型情報が積み 上げられている，これまでに，ヒトにおいて遺伝子 多型の存在が報告されている CYP 分子種は, CYP1A1, CYP1A2, CYP1B1, CYP2A6, CYP2B6, CYP2C8, CYP2C9, CYP2C18, CYP2C19, CYP2D6,

東北大学医学部附属病院薬剂部（干980-8574 仙台市青 葉区星陵町 1-1) 現所属: 東北薬科大学臨床薬剂学 （干981-8558 仙台市青葉区小松島 4-4-1）

*本総説は, 平成 14 年度日本薬学会奨励賞の受賞を記 念して記述したものである.
CTYP2E1, CYP3A4, CYP3A5 及び CYP3A7 などが ある. 1) 特に CYP2C19 及び CYP2D6に関しては数 多くの研究結果が報告されている。CYP2C19 は消 化性潰瘍治療薬のオメプラゾールなどを代謝する が，この分子種の Poor Metabolizer（PM）の頻度 は, 白人（約 5\%）に比べ日本人で高く, 約 15-20 \%と推定されている。最近では，ヘリコバク ター・ピロリの除菌効率が PM では著しく高いこ とを示唆する報告がなされており, 患者個々の遺伝 情報を基にした処方設計の必要性が指摘されてい る. ${ }^{2,3)}$ また, CYP2D6 は 60 種類以上の抗うつ薬, 抗不整脈薬, 抗精神病薬など臨床上重要な薬物を特 異的に代謝するために, 多型性を示す CYP の中で は最も重要な分子種である. CYP 以外の薬物代謝 酵素では, アザチオプリンやメルカプトプリンの代 謝に関与するチオプリン $S$ 一メチルトランスフェ ラーゼ（TPMT)，イリノテカンの代謝に関与する $\mathrm{UDP}$ 一グルクロノシルトランスフェラーゼ $1 \mathrm{~A} 1$ 
（UGT1A1），5-FU の代謝の関与するジヒドロピリ ミジンデヒドロゲナーゼ (DPYD)，イソニアジド の代謝に関与する $N$ 一アセチルトランスフェラー ゼ 2（NAT2）などに遺伝的な多型性が存在するこ

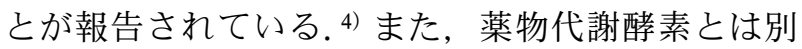
に薬剤の効果に影響を与える遺伝子マーカーや薬物 ターゲット分子の SNP も報告されている。例え ば，コレステリルエステル転送タンパク（CETP） 遺伝子の SNP は, 高脂血症薬プラバスタチンの薬 効とアソシエートしている. その他にも，アンジオ テンシン変換酵素（DCP-1）, $\beta 2$ アドレナリンレセ

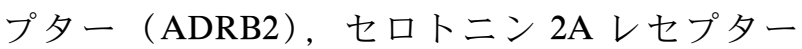
(HTR2A)，イノシトールポリフォスフェート 1一 フォスファターゼ (INPP1) などの SNP が薬効と アソシエートしていることが報告されている. ${ }^{4)}$ さ らには，ミトコンドリアDNA の遺伝子多型による アミノグリコシド系抗生物質の高頻度な副作用発現 も報告されている. 5)

このように，現在国内外において，これら薬剤反 応性遺伝子の SNP 解析は日進月歩で進展してい る。しかし，これらの SNPを有する患者に対し て, 臨床レベルで遺伝子診断を行い, 薬物の適正使 用・評価を行っている施設は非常に少ない。これに は少なくとも 2 つ原因が考えられる. 第 1 点とし て, フェノタイプージェノタイプのアソシエーショ ンスタディがまだ不十分であることにある。つま り，どの遺伝子のどの SNP を検出すれば，どのよ うなフェノタイプが予測できるかということを明確 にする必要がある。また，第 2 点としては，臨床現 場で運用できるような簡易, 迅速かつ正確な SNP 診断システム・プロトコールが整備されていないこ ともあげられる。しかし近年, SNP 解析技術は数 多く開発されているので，その目的・解析規模など に応じて最適の手法を選択できるようになってきて いる．既知の SNP を迅速かつハイスループットで 解析（タイピング）する方法は Invader 法, Sniper 法, TaqMan PCR 法, Hybridization Probe 法, SNPIT 法, Pyrominisequencing 法, Denaturing High Performance Liquid Chromatography (DHPLC) 法, MALDI-TOF/MS 法, NanoChip 法など数多く開発 されている. 特に臨床の現場では, 煩雑な操作を必 要とせず，多量の検体を短時間で処理することがで き, 様々な SNP の検出系を容易に構築でき, 十分
な技術の標準化，精度管理や精度保証がクリアされ る SNP 簡易診断システムの開発が強く望まれてい る.

これまでに我々は，薬剤反応性遺伝子の SNP 検 出のために蛍光プローブ (TaqMan Probe, SYBR Green I あるいは Hybridization Probe）を用いたり アルタイム PCR の開発を行ってきた. 現在, リア ルタイム PCR 用の検出機器としては，アプライド バイオシステムズの ABI PRISM 7700， 7000, GeneAmp 5700, ロシュモレキュラーバイオケミカ ルの LightCycler, バイオラッドの iCycler iQ, Cepheid の Smart Cycler などがある。このように 様々な SNP 検出技術と検出機器があるが, 今回は 我々が臨床応用 (外来患者の遺伝子診断に対応でき るもの）を目指して開発している方法についてのみ 述べる。 また，それらの臨床応用例についても若干 紹介する.

\section{SNP 検出法}

Allele-Specific Real-Time PCR Assay 近年, 2 種類の蛍光色素でラベルされたオリゴヌクレオチド である TaqMan プローブを用いて PCR を行い，そ の際に発光される蛍光を検出することにより, リア ルタイムで DNA 増幅を検出することができる TaqMan PCR 法が開発された。すでにTaqMan PCR 法は，DNA，RNAの定量や遺伝子多型診断の 診断に応用されている. TaqMan PCR 法による遺 伝子多型診断は, リアルタイムで DNA 増幅がモ二 ターできるので, 迅速な遺伝子多型診断を可能に し, さらに, 一度に PCR 装置の well 数分の検体 （本研究で使用した ABI PRISM 7700 では 96 wells） を調べることができる。しかし，従来の TaqMan PCR では, 野生型対立遺伝子, 変異型対立遺伝子 に各々特異的に結合する 2 種類の TaqMan プロー ブを用い，その結合安定性の差を利用して変異の有 無を検出していた（Fig. 1)。そのため，これらが 特異的に目的の対立遺伝子に結合するための温度条 件の設定が容易ではなく, 多種類の薬物代謝酵素遺 伝子多型を同時に検出するシステムを構築するには 問題があった．また，この方法は，1つの多型を検 出するのに高価な TaqMan プローブを 2 種類必要 とするため経済的にも問題があった。 そこで, 我々 は, 迅速に多量の検体の処理ができ, かつ複数の薬 剂反応性遺伝子 SNP を同時に検出可能なシステム 

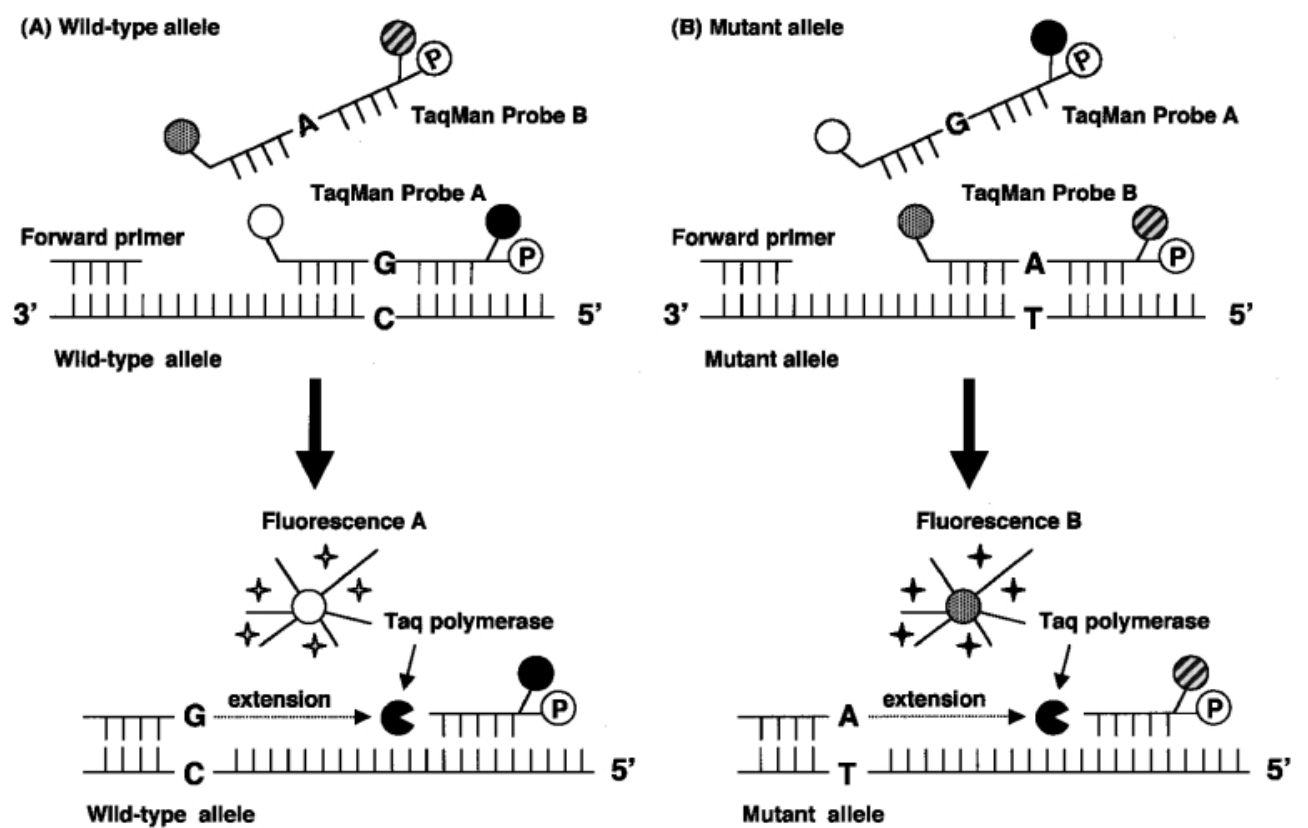

Mutant allele

Fig. 1. Principle of Traditional SNP Detection Method with TaqMan Probes

野生型アレルと変異型アレルに各々特異的にアニーリングする 2 種類の TaqMan プローブ（A 及び B ）を作製する.この際，それらのプロープの 5端 にラベルされる蛍光色素は異なる波長を有するものを用いる. PCR を行い, 伸張反応時に TaqMan プローブが分解され，発生する異なる波長の蛍光を検出 し遺伝子型を決定する。
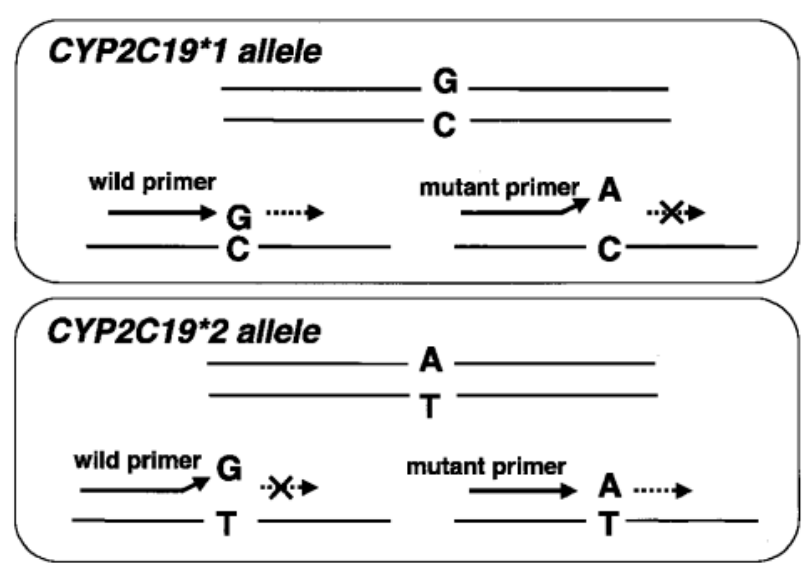

Fig. 2. Principle of SNP Detection Method in the Allele Specific PCR

変異部位の塩基配列が $3^{\prime}$ 端にくるように, 野生型アレルあるいは变 異型アレルに対してのみ特異的に伸張反応を起こす 2 種のプライマー (wild primer 及び mutant primer) を設計し PCR を行う。増幅反応が見 られれば，その特異的プライマーが反応するアレルを有することになる.

を構築する目的で, 対立遺伝子特異的増幅法 (Fig. 2)と TaqMan PCR を組合せた Allele-Specific（AS） Real-Time PCR 法を松原らの方法6)に準じて開発し た（Fig. 3)。その方法を以下に説明する。.まず末 梢血 $200 \mu \mathrm{l}$ あるいは唾液 $1 \mathrm{ml}$ から常法により DNA を抽出し，それを鋳型として，各薬剤反応性 遺伝子の SNP を検出できる対立遺伝子特異的増幅

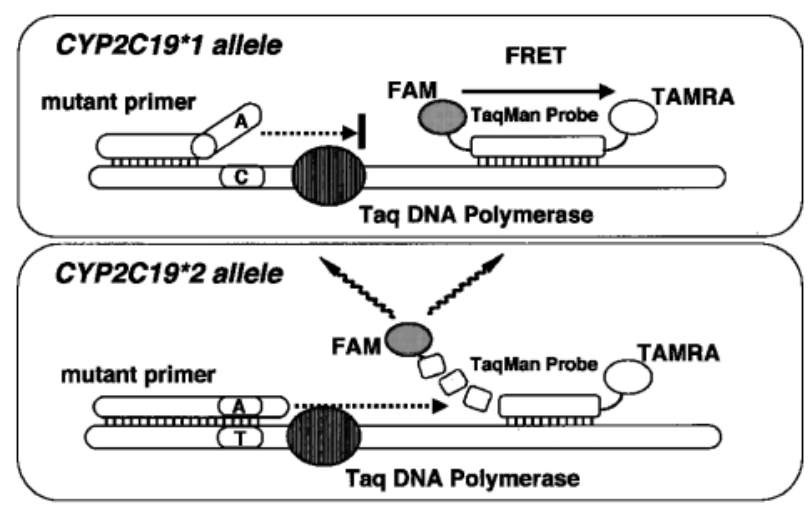

Fig. 3. Scheme of AS Real-Time PCR Assay for Detection of CYP2C19*2 Allele

野生型アレルに野生型プライマーを用いて反応した場合は、プライ マーの完全なアニーリングにより DNA ポリメラーゼで伸張反応が起こ り，その過程で TaqMan プローブが分解されて，5端にラベルされてい たレポーター蛍光色素（FAM）がクエンチャー蛍光色素（TAMRA）を 離れて蛍光発光が生じる。一方, 変異型アレルに野生型プライマーを用 いた場合は、プライマーの 3'端が鋳型 DNA とミスマッチしているため 伸張反応が起きず, 結果として Fluorescence Resonance Energy Transfer （FRET）現象により蛍光が生じない. 変異プライマーを用いた場合はこ の逆となる.

法用のプライマーセットをそれぞれ設計する. 次に それらの PCR 産物の配列内にハイブリダイズする ような 5'端を 6-carboxyfluorescein (FAM) レポー ター蛍光色素, 3端を 6-carboxytetramethylrhodamine（TAMRA）クエンチャー蛍光色素でラベル 
した TaqMan プローブを設計し，対立遺伝子特異 的増幅法と組み合わせて PCR を行う。通常， TaqMan プローブ上の 2 種類の蛍光色素は, 互いの物 理的距離が近いため, FRET (fluorescence resonance energy transfer) 現象によって蛍光強度が低 下した状態におかれている。対立遺伝子特異的 PCR プライマーと鋳型 DNA が一致した場合は PCR が進行し, TaqDNA ポリメラーゼの伸張反応 によって蛍光標識プローブが分解され, 遊離したレ ポーター色素が蛍光を発する. 検出にはアプライド バイオシステムズ社 ABI PRISM, GeneAmp 5700 あ るいはロシュダイアグノスティックス社 LightCycler 等を利用し, サイクルごとの蛍光強度を測定す ることにより，PCR 産物を定量することを可能に している. 反応条件は $50^{\circ} \mathrm{C}$ で 2 分間, $95^{\circ} \mathrm{C}$ で 10 分間の変性後, $95^{\circ} \mathrm{C}$ で 15 秒, $60^{\circ} \mathrm{C}$ で 60 秒の反応 を 35-40 サイクル行う。野生型ホモ接合体，へテ 口接合体及び変異型ホモ接合体の鑑別は, 蛍光強度 が検出可能になってくる PCR サイクル数 (Threshold cycle: $\mathrm{Ct}$ ) を用いている。すなわち，

\section{A. CYP2C19*1/*1}

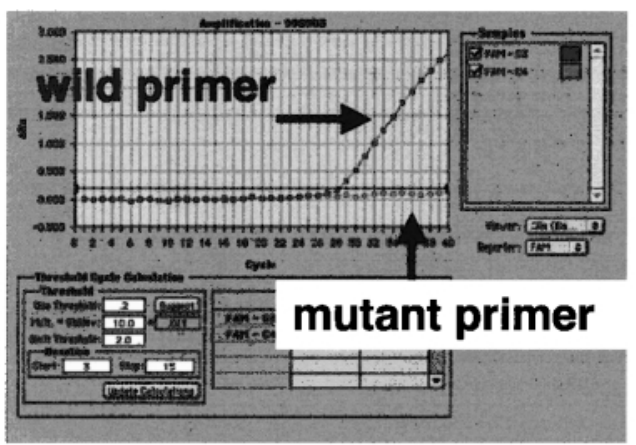

C. CYP2C19*2*2

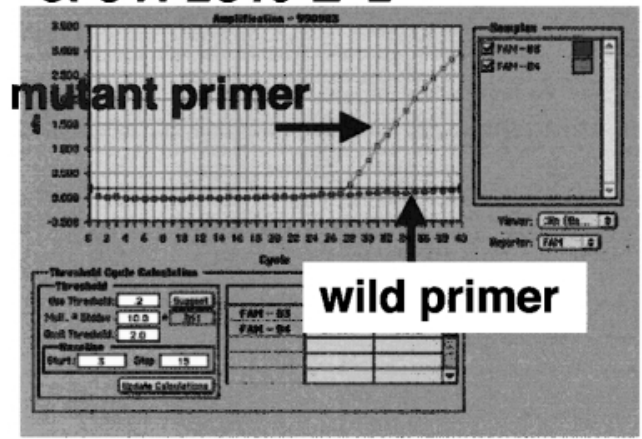

反応終了後, 得られたデータをコンピュータソフト 上で自動解析し，野生型プライマーで得られた Ct 值 (Ctwt) から変異型プライマーで得られた Ct 值 (Ctmt) を差し引いた值により，変異の有無を確認 した。その大きさがー3 以下であれば野生型ホモ接 合体， -3 から 3 の間であればへテロ接合体， 3 以 上であれば変異型ホモ接合体であると判断している.

実際にCYP2C19*2 アレルの検出を例に説明す る. 上記の反応系に従い, リアルタイム PCR を行 つた。 その結果, 横軸に PCR サイクル数, 縦軸に 蛍光シグナル $(\Delta \mathrm{Rn})$ をとると, Fig. 4 のようなプ ロファイルが得られる。ここで，FAM の蛍光強度 を蛍光リファレンスであるROXによって補正した 標準化蛍光シグナル（Rn）とする。 $\Delta \mathrm{Rn}$ はこの標 準化蛍光シグナルから PCR 初期サイクルのレポー ター蛍光シグナル (ベースライン) を差し引いた值 である.さらに，このプロファイル上で，蛍光シグ ナルの増加を解析アルゴリズムが初めて検出したサ イクル数を $\mathrm{Ct}$ とする. 今回の検出では，すべての 多型検出において $\Delta \mathrm{Rn}$ が 0.200 を越えた時のサイ

\section{B. CYP2C19*1/*2}

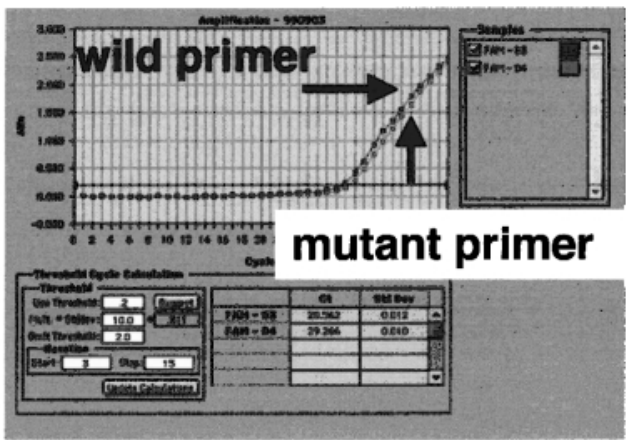

Fig. 4. Profiles of $C Y P 2 C 19$ Genotyping

横軸は PCR サイクル数を示し, 縦軸は蛍光強度を示す。図中の A, B, C は, 各々 $C Y P 2 C 19^{*} 1 /{ }^{*} 1, C Y P 2 C 19^{*} 1 /{ }^{*} 2, C Y P 2 C 19^{*} 2 /{ }^{*} 2$ の増幅プロファイル を示している 
クル数を $\mathrm{Ct}$ とした。野生型ホモ接合体 $(\mathrm{G} / \mathrm{G})$, ヘテロ接合体（G/A） あるいは変異型ホモ接合体 (A/A) で，それぞれ特徵的なプロファイルが得ら れる（Fig. 4)。また，(Ctwt-Ctmt）值は野生型木 モ接合体, ヘテロ接合体及び変異型ホモ接合体の值 に有意な差が認められた（ $p<0.001 ） （$ Fig. 5)。従 来法である PCR-RFLP 法により再確認した CYP2C19 の遺伝子型は, AS Real-Time PCR 法で 得られた結果とすべて一致した。

現在までに当研究室においては，Fig. 6 に示した 21 遺伝子 34SNP の検出を同一反応条件で行えるプ ライマー及び蛍光標識プローブのセットが設計でき ている. ${ }^{7-10)}$ 検出時に, PCR サイクルの増加に伴 い，ミスマッチを持つプライマーによっても非特異

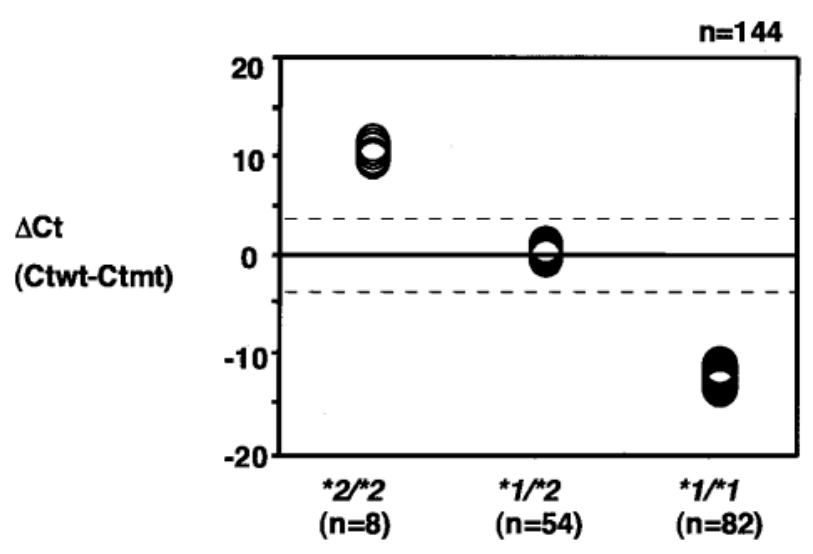

Fig. 5. The Relationship between the Difference of Threshold Cycle (Ctwt-Ctmt) and Genotypes of $C Y P 2 C 19^{*} 1 /{ }^{*} 1,{ }^{*} 1 /$ $* 2$ and $* 2 / * 2$

野生型プライマーを用いたときの $\mathrm{Ct}$ 值 $(\mathrm{Ctwt})$, 変異型プライマー を用いたときの $\mathrm{Ct}$ 值 $(\mathrm{Ctmt})$ を求め, その差 $\Delta \mathrm{Dt}(\mathrm{Ctwt}-\mathrm{Ctmt})$ を算出 する. これらの值より CYP2C19 の遺伝子型を客観的に評価できる.
的な増加が認められたものも存在したが，(CtwtCtmt）值を計算すると，すべてにおいて野生型木 モ接合体, ヘテロ接合体あるいは変異型ホモ接合体 の值に有意な差が認められた。これにより，ここに あげたすべての薬剤反応性遺伝子の SNPタイピン グが可能となった.

また, TaqMan プローブは比較的高価であり, 診 断コストを下げるために対立遺伝子特異的増幅法と SYBR Greenを組み合わせて PCR を行った。 SYBR Green は二本鎖 DNAに特異的に取り込ま れ，蛍光を発する特徵があり，また，TaqMan プ ローブと比較すると安価な蛍光色素である. ただし TaqMan プローブを用いた場合, 鋳型 DNA 2 種 のプライマーと 1 種の蛍光プローブの 3 箇所で認識 するのに対し, SYBR Green 蛍光色素を用いた場合, 2 種類のプライマーのみで鋳型を認識するため, そ の特異性は若干低下する可能性がある. 結果的には 我々がターゲットとしたほとんどの SNPにおいて SYBR Green での検出は可能であった. ${ }^{11)}$ さらに, SYBR Green を用いた系はキャピラリー式サーマル サイクラー LightCycler でも応用可能であり, 約 30 分という短時間で SNP の検出が可能となった.

AS Real-Time PCR 法を用いた SNP 検出系は煩 雑な操作を必要とせず, 短時間（約 1.5-2 時間） で多量の検体を処理できる特徵があり, しかも唾液 由来の DNA で診断可能であった. 従来の対立遺伝 子特異的増幅法では, 最終的な PCR 産物の量をゲ ル上で判定していたために反応条件の厳密な設定が 不可欠で, 反応条件のわずかな変動でも偽陽性が出 る危険性があった。本法では, PCR の各サイクル

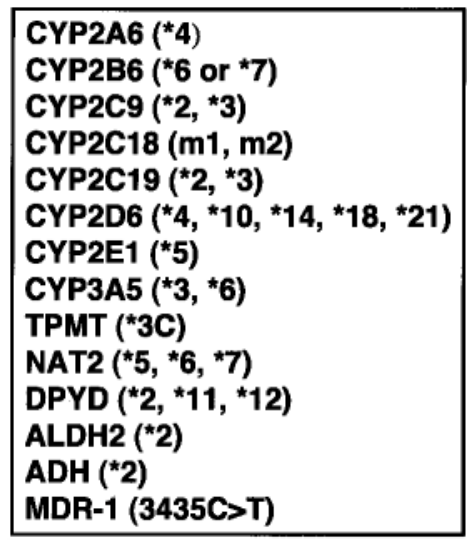

DCP-1 (287-bp Ins/Del)

CETP (Taq I B1 vs B2, 297G>A)

HTR2A (102T>C)

ADRB2 (46A $>\mathrm{G}, 79 \mathrm{C}>\mathrm{G})$

INPP1 $(973 \mathrm{C}>\mathrm{A})$

SDF-1 (3'A vs 3'+)

mtDNA (1555A>G)

\section{Genes \\ 34 SNPs}

Fig. 6. Simultaneous Detection of 34 SNPs Using AS Real-Time PCR Assay

この論文の投稿時点で, AS-Real Time PCR 法により同時検出できる薬剤反応性遺伝子多型であり, 現在さらに検出多型を増やしている. 
で蛍光をモニターし，その増加を経時的に追いかけ ることで, より精度の高い遺伝子診断が可能であ る. また, 電気泳動のような PCR 後の操作は一切 不要なため，簡便であるのみならず，PCR につき ものの交叉污染の心配もない. 反応終了後はチュー ブの蓋を開けることなく廃棄することができる.

\section{Hybridization Probe Assay この方法は，2 本} の蛍光プローブによる PCR 産物及び SNP のリア ルタイム検出法である（Fig. 7)。まず，目的の配 列を増幅できるようなプライマーを設計する，次 に，それらの PCR 産物の配列内にハイブリダイズ するような $3^{\prime}$ 端をフルオレセインでラベルしたプ ローブを設計する。それとは別に5 端を LC Red640 蛍光色素でラベルし，3'端をリン酸化した プローブを設計する.このプローブは, 鋳型 DNA にハイブリダイズするときにフルオレセインと LC Red640 の 2 つの蛍光色素が 1一5 ヌクレオチドの近 距離にあるように設計する。それぞれのプライマー とプローブを一本のキャピラリーに分注し，混合さ せた反応液中で PCR を行う。アニーリングの際に プローブが鋳型 DNA にハイブリダイズし，2つの 蛍光色素が近づくと FRET 現象によって蛍光を発 する．PCR 産物が増加するに従って，アニーリン グ時に検出される蛍光強度も増加する。 さらに
SNP 検出は融解曲線分析によって行われる. 反応 終了後, 蛍光シグナルをモニターしながら, 温度を ゆっくりと上げて DNA 二重鎖の融点に至るまでの カーブから特異性を決定する。つまり，ある高温に 達するとまず Tm の低い方のプローブが解離し, フルオレセインと LC Red640 の距離が離れるため 蛍光強度が急激に低下する。プローブ内にミスマッ チが存在すると, 完全にマッチした配列よりも解離 しやすくなり，Tm 值が低い值となる (Fig. 8)。検 出には LightCycler を用いて, サイクルごとの蛍光 強度を測定することにより，PCR 産物を定量し， また，融解時の蛍光強度を測定することで，PCR 産物のプローブに対する $\mathrm{Tm}$ 值の差から $\mathrm{SNP}$ を検 出することを可能にしている. 野生型ホモ接合体, ヘテロ接合体, 変異型ホモ接合体の判別は, 融解曲 線における蛍光強度を $-\mathrm{dF} / \mathrm{dT}$ でプロットしたと きのピーク值（Tm 值）を用いている，つまり，反 応終了後, 得られたデー夕を解析し, 融解曲線の ピークによって変異の有無を確認した。野生型に特 異的な $\mathrm{Tm}$ 值のみを示した場合は野生型ホモ接合 体，変異型に特異的な $\mathrm{Tm}$ 值のみを示した場合は 変異型ホモ接合体，2つのピークを示したときはへ テロ接合体であると診断した，反応温度条件は，95 ${ }^{\circ} \mathrm{C} 10$ 分間処理後, $95^{\circ} \mathrm{C} 15$ 秒間, $50^{\circ} \mathrm{C} 10$ 秒間, 72
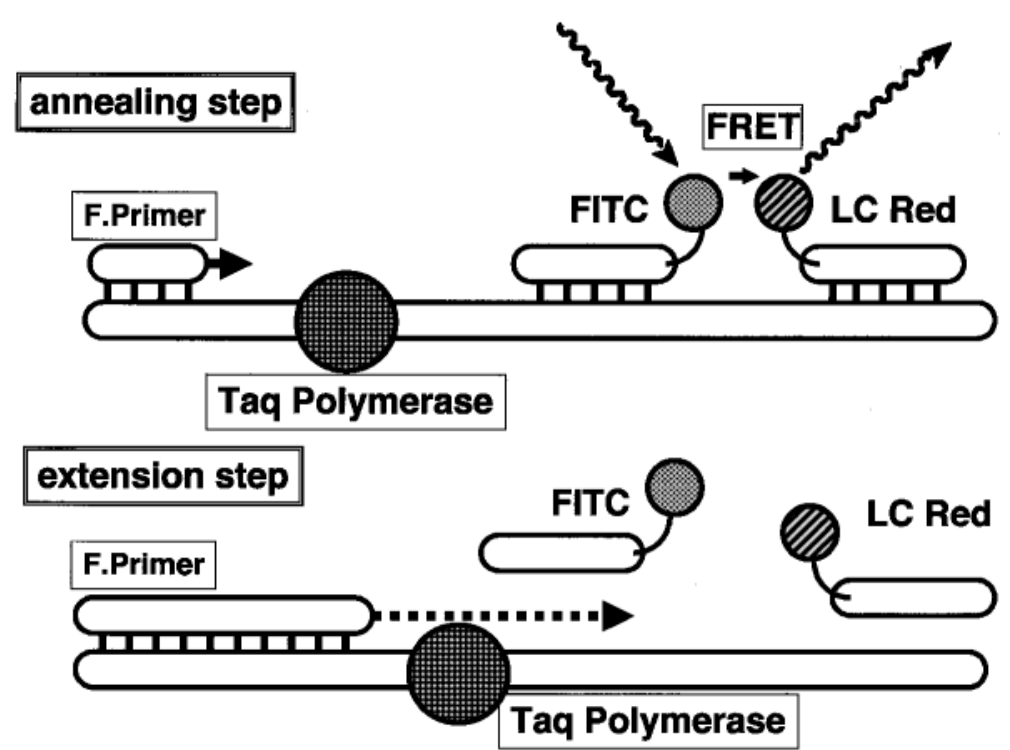

Fig. 7. Principle of Hybridization Probes Format

Hybridization Probe 法は PCR 産物の配列内にハイブリダイズするような $3^{\prime}$ 端をフルオレセイン（FITC）でラベルしたプローブと 5端を LightCycler Red (LC Red) でラベルし 3端をリン酸化したプローブを用意する. 2 つの蛍光色素が近づくと FITC の蛍光波長が LC Red を励起し蛍光を発する. その 後、フォワードプライマー (F. Primer) の位置から Taq DNA ポリメラーゼによつた伸長反応が進行するためプローブは分解される. PCR 産物が増加する に従って，アニーリング時に検出される蛍光強度も増加する。 


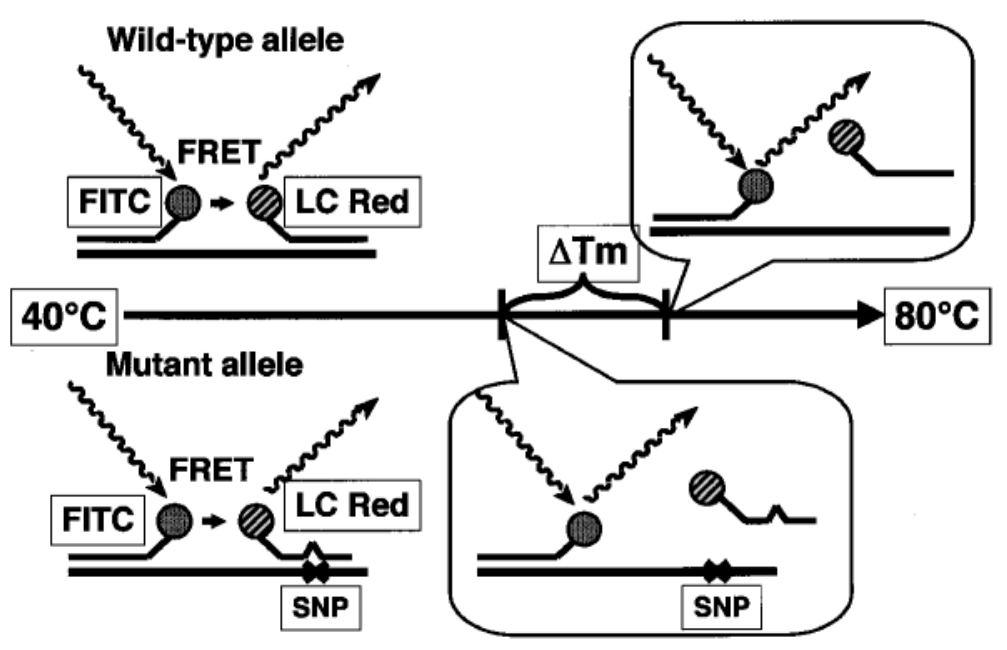

Fig. 8. Principle of SNP Detection Method with Hybridization Probes

SNP 検出は, Melting Curve 解析によって行われる. 反応終了後, $40^{\circ} \mathrm{C}$ 付近まで温度を下げ, 蛍光シグナルをモニターしながら, 温度をゆっくりと上昇 させる. 変異が存在する場合, その部分に設計した変異検出プローブ（LC Red ラベル）とターゲット間のミスマッチにより, そのハイブリダイゼーション は不安定となり，プローブが変性により解離し，FITC ラベルのアンカープローブと離れて FRET 現象が起こらなくなり蛍光が減衰する．野生型ではミスマ ッチが起こらないため, ここではより高い $\mathrm{Tm}$ 值でハイブリダイゼーションしている. よって, 野生型アレルと変異型アレルでの融解温度に差（ムTm）が 生じ，これを利用し遺伝子型を判定する。

${ }^{\circ} \mathrm{C} 10$ 秒間のサイクルを 40 サイクル行った。 その後, $95^{\circ} \mathrm{C} 30$ 秒間, $40^{\circ} \mathrm{C} 45$ 秒間処理後, $0.1^{\circ} \mathrm{C} / \mathrm{sec}$ で 80 ${ }^{\circ} \mathrm{C}$ まで上昇させ， $40^{\circ} \mathrm{C} 30$ 秒間処理した。

現在，当研究室においては CETP （297G>A）, ADRB2 $(46 \mathrm{~A}>\mathrm{G}, 79 \mathrm{C}>\mathrm{G}), \mathrm{HTR} 2 \mathrm{~A}(102 \mathrm{~T}>\mathrm{C})$, Mitochondrial DNA $(1555 \mathrm{~A}>\mathrm{G})$, INPP1 (973C $>$ A）の 6 種類の SNP の Hybridization Probe 法によ る同時検出系を構築している (Fig. 9). プライマー とプローブの設計は, 以下の点に留意して行った.

(1) フルオレセインと LC Red640 ラベルされたど ちらのプローブに SNP が位置するかはプライ マーやその配列の GC\% を考慮して決定する.

(2) 設計時の基準としては，SNP を配列内に含ん でいるプローブの Tm 值を含んでいないプ ローブのものより $5^{\circ} \mathrm{C}$ 以上低くする.

(3) 塩基間の結合強度に注意してプローブを設計す る.

特に(3)に関しては，SNP の有無による融解曲線 の $\mathrm{Tm}$ 值は, 一塩基のみのミスマッチによって差 を出すため, 塩基間の結合強度が重要な因子とな る。例えば, CETP は $\mathrm{G} \rightarrow \mathrm{A}$ 変異であり, センス 鎖でプローブを設計すると, 変異型の鋳型 DNA と プローブのミスマッチは $\mathrm{G}: \mathrm{T}$ ミスマッチとなる.

このミスマッチは非常に安定であり, 野生型と変異 型のアレル間で $\mathrm{Tm}$ の差があまり出ないことが予 想される。そこで, より不安定な $\mathrm{C}: \mathrm{A}$ ミスマッチ

\section{Melting Peak}

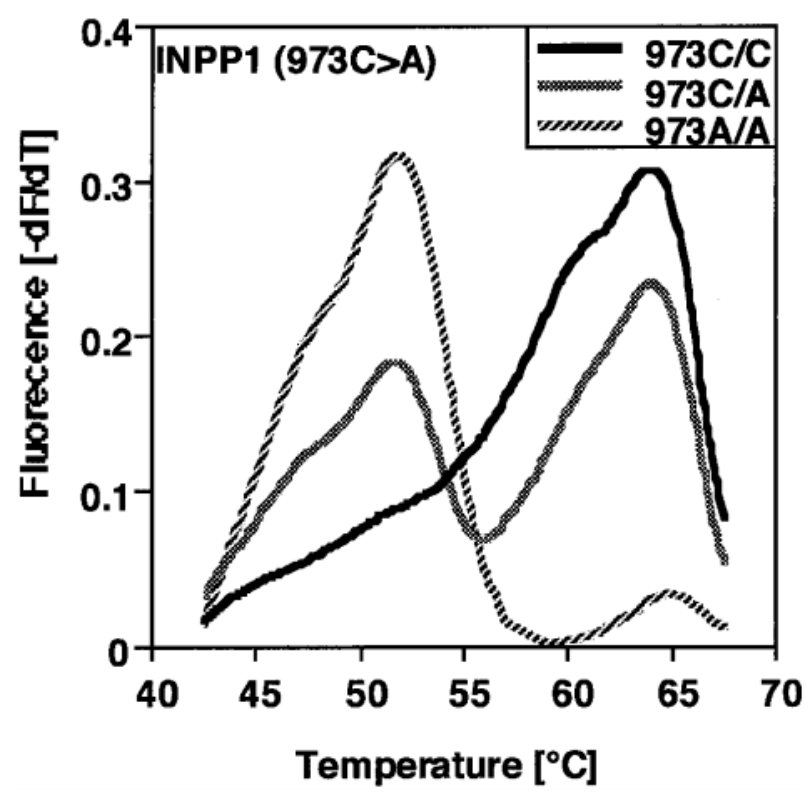

Fig. 9. Profile of Melting Curve Analysis

INPP1 973C >A 変異の検出プロファイルを示す．C/C 型ではプロー ブとアレル間が完全にマッチしているため, $65^{\circ} \mathrm{C}$ 付近に単一のピークを 示している，それに対し， $\mathrm{A} / \mathrm{A}$ 型ではプローブとアレル間ミスマッチが あるために, それより低い $\mathrm{Tm}$ 值 $\left(50^{\circ} \mathrm{C}\right)$ で解離している. また, C/A 型はそれらのピークを両方有する 2 峰性のカーブが検出される.

となるようにアンチセンス鎖でプローブを設計した. HTR2A についても同様に，アンチセンス鎖でプ ローブを設計した。その結果，すべての反応系にお いて, 野生型と変異型の木モ接合体はそれぞれ固有 
の $\mathrm{Tm}$ 值を示し, ヘテロ接合体では野生型と変異 型両方のピークを有する 2 峰性となつた. それらの 検出結果は，すべて AS-Real Time PCR Assayを用 いて診断した結果と一致した.また，この 6 種類の SNP はすべて同一の検出条件で測定可能であつ た. ${ }^{12)}$

この検出法は LightCycler を用いることで反応時 間を 40 分に短縮し, 融解曲線によって遺伝子多型 を迅速に検出する方法である. 現在までに, 他の施 設において，この方法による TPMT, ${ }^{13)} N A T 2,{ }^{14)}$ $C Y P 2 D 6^{*} 4^{15)}$ などの遺伝子多型検出系が確立され ている. 同法は検出器本体も小型であることから, 臨床の場に適用しやすいと考えられる. また， 1 本 のキャピラリーで検出可能であり, 検出後は密閉し たまま廃棄することができるため, 污染の危険性も 少ない. 今回構築した SNP の検出系において, 反 応温度条件はすべて同一になるように設定している ため, 一度に多種類の遺伝子型を検出することが可 能である。

\section{ABI PRISM 7700 と LightCycler の比較＼cjkstart現在,} 当研究室においては基本的に AS Real-Time PCR Assay は ABI PRISM 7700 を用いて, 一方 Hybridization Probe Assay は LightCycler を用いて行っ ているが，それぞれの長所と短所を感じている。つ まり LightCycler は温度調節を空気によって行って おり，熱伝導率がよいガラスキャピラリーを用いる ため，短時間で PCR を行うことが可能である.し かし，それゆえに条件設定が難しく，またガラス製 のキャピラリーを用いるためサンプル調製が煩雑で あるという点をもつ。 また, 一度に最大で 32 検 体しか測定できない. AS Real-Time PCR で用いた ABI PRISM 7700 は最大 48 検体を一度に検出で き，またサンプル調製が比較的簡便であるという利 点をもつ. しかし, 一つの SNP の検出に 2 本のチ ユーブを必要とする。 また， LightCycler に比べる と反応時間が長いという久点がある.

そこで血液から DNA 抽出後, サンプル調製 $\rightarrow$ 測 定 診断までの所要時間を計測した。まず, 1 個人 における数種類の SNPについて遺伝子診断する場 合を想定して検討した。 ある 1 個人の検体に対して CETP $(297 \mathrm{G}>\mathrm{A}), \operatorname{ADRB} 2(46 \mathrm{~A}>\mathrm{G}, 79 \mathrm{C}>\mathrm{G})$, HTR2A $(102 \mathrm{~T}>\mathrm{C})$, Mitochondrial DNA (1555A> G), INPP1 (973C >A）の 6 種類の SNP を検出し
た.ABI PRISM 7700 ではサンプル調製から遺伝 子型の判定まで 2 時間 35 分要したのに対し, LightCycler では 1 時間 35 分ですべての操作が終了 した. 次に 1 種類の SNP について多検体の遺伝子 診断をする場合を想定して検討した。 CETP (297G $>A ）$ 遺伝子多型について 48 サンプルの遺伝子診 断を行った，先に述べたように LightCycler では一 度に 48 サンプル測定することはできないため， 2 回に分けて測定した。 その結果, ABI PRISM 7700 は 2 時間 35 分要したのに対して, LightCycler は 3 時間 35 分を要した。この中で，48 検体の調製に要 する時間は ABI PRISM 7700 で 35 分であつたのに 対し, LightCycler では 2 回に分けなければならな いため, 40 分を要した。 コスト面では, AS RealTime PCR Assay では1つの SNP を検出するのに 要する費用は510 円, Hybridization Probe 法では 549 円であり，ほぼ同程度であった。

\section{SYBR Green I PCR/Melting Curve Assay AS}

Real-Time PCR Assay $ゃ$ Hybridization Probe Assay は一塩基置換のような遺伝子多型の検出には非 常に有効であるが, 数十〜数百塩基の挿入・欠失の 遺伝子多型検出への応用は困難である. また, 蛍光 プローブは比較的高価であり，このプローブを用い ない安価な SNP 検出法も求められている. そこ で，蛍光色素として SYBR Green I を用いて PCR を行い, PCR 産物のサイズや GC\% 含量の違いに よる Tm 值の差を利用した Melting Curve 解析によ り遺伝子型を判定する診断法の構築を試みた。

Figure 10 に示したように, SYBR Green I は二本鎖 DNA に取り込まれて蛍光を発するため，この蛍光 色素を用いて PCR を行うと, PCR 産物の増幅とと もに蛍光強度も増幅される。遺伝子多型検出は Hybridization Probe 法と同様に, Melting Curve 解 析によって行った. PCR 終了後, 蛍光シグナルを モニターしながら, 温度をゆっくりと上昇させると 二本鎖 DNA の融点に至り, 一本鎖 DNA になる. このとき, 二本鎖 DNA に取り込まれていた SYBR Green I が放出され，蛍光強度が急激に低下する。 この Melting Curve の最大変化点を, 蛍光強度の負 の一次微分值 $(-\mathrm{dF} / \mathrm{dT})$ を温度に対してプロット したグラフから，異なる Tm の単一のピークと し, 遺伝子型を判定する. 数十〜数百塩基の挿入 • 欠失の遺伝子多型では, PCR 産物のサイズがそれ 
ぞれのアレル間で大きく異なるため, 融解温度に差 が生じる。このアレル特異的に得られる RCR 産物 の $\mathrm{Tm}$ 值を利用して遺伝子型の判定を行う。検出 にはアプライドバイオシステムズ社の GeneAmp 5700 あるいは LightCyclerを用いて行った。5Hydroxytriptamin transporter (5-HTT) は 44 bp 挿 入 - 欠失型と $125 \mathrm{bp}, 167 \mathrm{bp}$ 挿入型などの数種類の 遺伝子多型が存在し, セロトニン選択的再取り込み

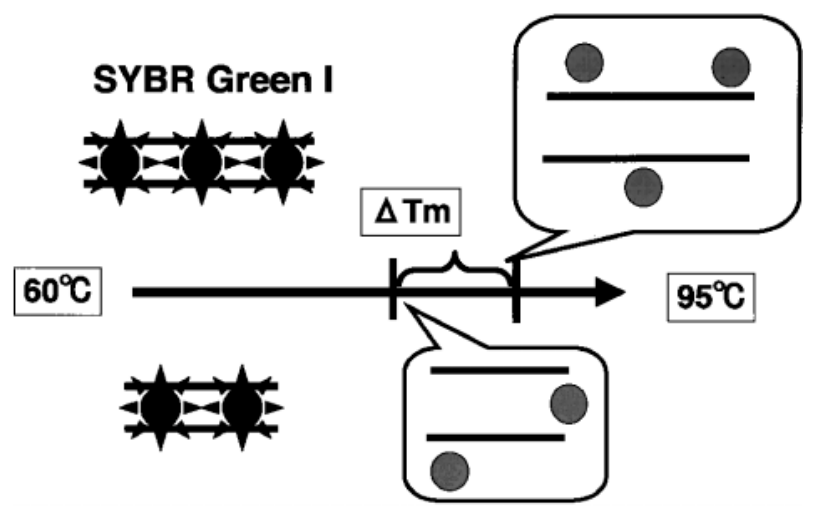

Fig. 10. Schematic Representation of Insertion/Deletion Polymorphisms with SYBR Green I

PCR 終了後, 蛍光シグナルをモニターしながら, 温度を $60^{\circ} \mathrm{C}$ から $95^{\circ} \mathrm{C}$ までゆっくりと上昇させると二本鎖 DNA の融点に至り、一本鎖 DNA になる. このとき, 二本鎖 DNA に取り込まれていた SYBR Green I が放出され, 蛍光強度が急激に低下する. 数十〜数百塩基の挿入 - 欠失 による PCR 産物のサイズがそれぞれのアレル間で大きく異なるとこの最 大変化点に大きな差 $(\Delta \mathrm{Tm})$ が生じる。このアレル特異的に得られる PCR 産物の $\mathrm{Tm}$ 值を利用して遺伝子型の判定を行う.
阻害薬 SSRI (serotonin selective reuptake inhibitor) の効果発現と相関性をもつことが示唆されている. 今回は $44 \mathrm{bp}$ の挿入 - 欠失型遺伝子多型の検出を行 つた（Fig. 11）。挿入塩基部位を挟むようにして設 計したプライマーを用いて PCR を行うと, long (1) 型アレルは $103 \mathrm{bp}$, short（s）型アレルは $59 \mathrm{bp} の$ PCR 産物がそれぞれ得られた。PCR 後, Melting Curve 解析を行った結果，1型アレルホモ接合体は $\mathrm{Tm}$ 值約 88.6 に単一のピークが得られた。それに 対して, s 型アレルホモ接合体は $\mathrm{Tm}$ 值 85.0 に単一 のピークが得られた。へテロ接合体はそれら両方の ピークを組み合わせた 2 つピークが得られた (Fig. 11)。また，同様の方法で, DCP-1の 287 bp の挿入 ・佚多型も検出可能であった. ${ }^{16)}$

今回構築した挿入・欠失型遺伝子多型検出法は, AS Real-Time PCR 法と異なり，一本のチューブで 反応を行うことができるため, 約半分のコストで SNP を検出することができる。 また, GeneAmp 5700 を用いた場合，一度に 96 の検体を約 2 時間で, LightCycler を用いた場合, 一度に 32 の検体を約 40 分で検出することが可能である. AS Real-Time PCR 法や Hybridization Probe 法と比較して, 高価 な蛍光プローブを用いることなく，安価な SYBR Green I を利用するため，検出コストが低い．また 1 本のチューブ又はキャピラリーで検出可能なた
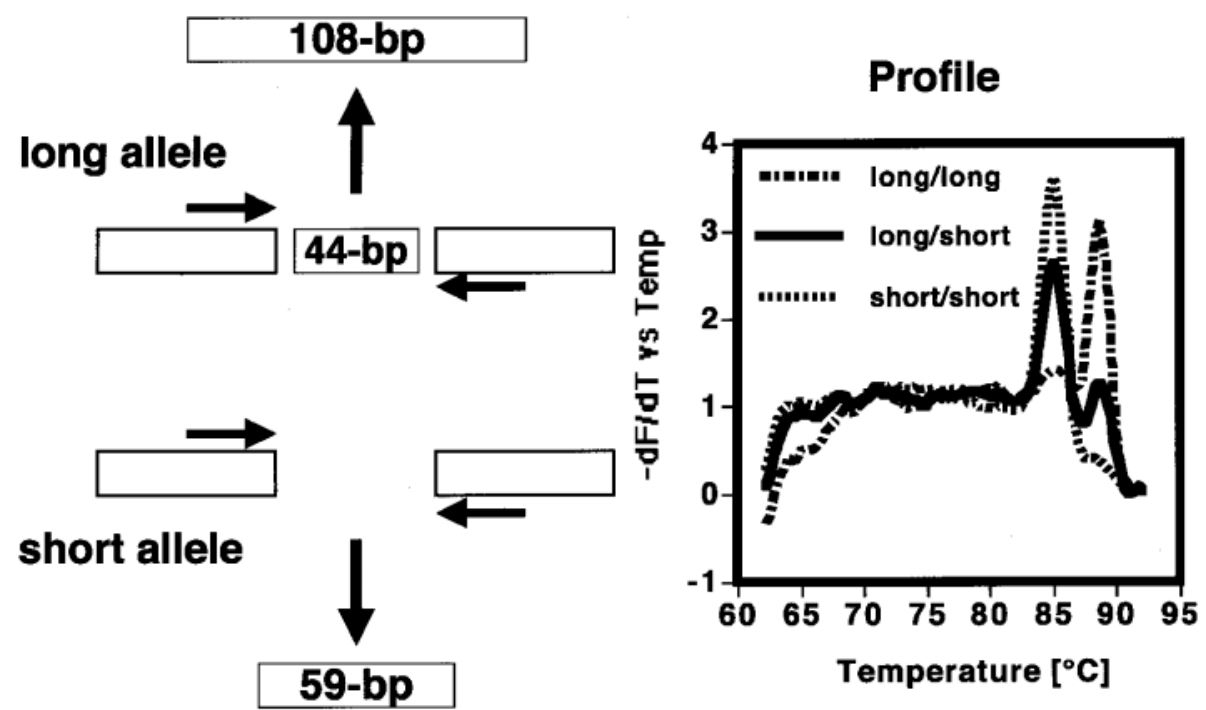

Fig. 11. Melting Curve Analysis with SYBR Green I for Detection of 5-HTT Long/Short Polymorphism

挿入塩基部位を挟むようにして設計したプライマーを用いて PCR を行うと, long 型アレルは $108 \mathrm{bp}$, short 型アレルは $59 \mathrm{bp}$ の PCR 産物がそれぞれ得 られる. long 型アレルホモ接合体は Tm 值約 88.6 に単一のピークが得られた. それに対して, short 型アレルホモ接合体は $\mathrm{Tm}$ 值 85.0 に単一のピークが得

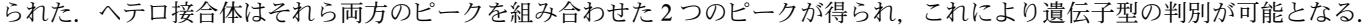


め, サンプル調製が比較的短時間ですみ，一度に多 数の検体を処理できるというメリットを持つ.

\section{臨床応用}

臨床研究を行う前に 現在, 本邦において遺伝 子解析研究を行う場合は，3 省庁による「ヒトゲノ ム・遺伝子解析研究に関する倫理指針」を遵守しな ければならない，我々の研究も基本的に本邦におけ る「ヒトゲノム・遺伝子解析研究に関する倫理指針」 及び「東北大学医学部附属病院における遺伝子診断 及び遺伝子解析研究における遵守事項」を基本原理 として行われている。しかし，実際の現場では，倫 理指針の制定が最近行われたこともあり，まだ手探 り状態で研究を進めている施設が多いのではないだ ろうか. 下記に, 我々が行っている遺伝子解析研究 の流れを示した.

(1) 検体採取の方法など研究プロトコールの作成

(2) 臨床医への依頼

(3) 倫理委員会へのプロトコール提出, 審査, 修 正, 承認

(4) 薬剤師による患者への説明同意

(5) 医師あるいは看護婦による検体採取

（6) 薬剤部での個人情報匿名化

(7) 遺伝子解析

(8) データベース化

(9) 医師への報告書作成

(10) 処方設計の修正協議

(11) 患者の容態観察, 改善確認

(12) 倫理委員会へ研究状況の報告

$N A T 2$ 遺伝子多型検出によるイソニアジド投与患 者の副作用発現回避結核治療薬イソニアジド （INH）の $N$-アセチル化能の個人差も，ヒトにお ける $N$-acetyltransferase2（NAT2）遺伝子の多型性 によって引き起こされることが古くから知られてい る. NAT2 はアセチル化活性により rapid acetylator (RA), intermediate acetylator (IA), slow acetylator（SA）に分類される. SA の頻度は白人種では約 $50 \%$ であるのに対して，日本人では約 $10 \%$ であ る. 現在 10 種類以上の変異が見い出されている が, 日本人では $N A T 2 * 4$ (野生型アレル) 以外の 3 種類の変異 $(N A T 2 * 5, N A T 2 * 6$ 及び $N A T 2 * 7)$ で ほぼ $100 \%$ のA を説明できる. 現在, 当研究室に おいて, INH 投与患者における副作用発現と $N A T 2$ 遺伝子多型に関する数症例を経験し, 遺伝子
診断による副作用発現回避システムの構築を行って おり，ここでは，その一部を紹介する.

症例 1 患者は, 混合性結合織病及び突発性血小 板減少性紫斑病と診断された 25 歳の女性である. 免疫抑制作用のためプレドニゾロン, またプレドニ ゾロンの胃腸障害防止・治療のためファモチジン及 びテプレノン, プレドニゾロンの易感染防止のため INH, 貧血改善のためアスコルビン酸とクエン酸 第一鉄ナトリウム, 不眠症状のためエチゾラムを投 与された。薬物療法を開始後から悪心・嘔吐は発現 した。 それら副作用の発現は週 2 回で, 朝の服薬後 約 1 時間であった。薬物動態に影響を及ぼす肝機能 及び腎機能の指標となるAST, ALT, BUN には特 に異常值は見い出されなかった。また，服用薬剤の 薬学的管理の結果, 重複投与, 投与禁忌, 慎重投 与, 相互作用などは認められなかった。服用薬剤の 悪心・嘔吐の発現頻度を調べたところ, クエン酸第 一鉄ナトリウムの副作用である可能性も否定できな かった。しかし, 副作用発現時期が INH の服用日 と一致するため, その代謝酵素であるNAT2 の遺 伝子多型を疑つた. 本研究は東北大学医学部倫理委 員会より承認されたプロトコールに則り, 患者に十 分な説明がなされ同意が得られた後行われた.ゲノ ム DNA は，末梢血 $200 \mu \mathrm{l}$ より抽出した. 抽出には， QIAamp DNA Mini Kit（キアゲン）を用いた。 $N A T 2$ 遺伝子多型の検出は, AS Real-Time PCR 法 を用いた。 NAT2 遺伝子型を解析した結果, 野生型 の遺伝子型が $N A T 2^{*} 4 /{ }^{*} 4$ であるのに対し, 患者の 遺伝子型は $N A T 2^{*} 7 / * 7$ の変異型木モ接合体であっ た.これらの結果を基に, 担当医, 担当薬剤師及び 筆者らの間で, 同薬剤の投与を中止することとし た．その後，患者の悪心・嘔吐は消失した。

症例 2 患者は，全身性エリテマトーデスと診断 された 41 歳の男性である. 免疫抑制作用のためプ レドニゾロン, プレドニゾロンの易感染防止のため 週 2 回 INH を投与された。 また, 酢酸トコフェ ロール，アスコルビン酸及びベラプロストナトリウ ムも補助的に投与された。薬物療法開始後約 1 力月 を経過した際, INH 投与日に限り $39^{\circ} \mathrm{C}$ 台の発熱が 出現した. 副作用の発現は週 2 回で, 朝の服薬後約 1 時間であった。薬物動態に影響を及ぼす肝機能及 び腎機能の指標となるAST, ALT, BUNには特に 異常值は見い出されなかった。また, 服用薬剤の薬 
学的管理の結果, 重複投与, 投与禁忌, 慎重投与, 相互作用などは認められなかつた。症例 1 と同様 に, 患者の NAT2 遺伝子型を解析した結果, NAT2 ${ }^{*} 6 /{ }^{*} 7$ の変異型コンパウンドヘテロ接合体であつ た.これらの結果を基に, 担当医, 担当薬剤師及び 報告者の間で，同薬剤を他剤に変更することとし た. その後, 患者の発熱は消失した.

これらの症例の他にも, Table 1 に示したような $N A T 2$ 遺伝子多型が原因と予想される副作用発現例 が見い出され, 現在では, Fig. 12 に示すような遺 伝子診断による副作用回避システムを実際の臨床の 現場で試験的に運用している。もし，NAT2 遺伝子 多型とこのような副作用発現の関係が明確になれ ば，薬物療法開始前にNAT2 遺伝子多型を判定す ることにより，副作用の発現しやすい患者を推定す

Table 1. Associations of NAT2 Genotypes and INH Induced -ADRs

\begin{tabular}{|c|c|c|c|c|}
\hline No. & $\begin{array}{l}\text { Side } \\
\text { effects }\end{array}$ & $\begin{array}{c}\text { Genotypes } \\
\text { (wild-type: } * 4 / * 4 \text { ) }\end{array}$ & $\begin{array}{l}\mathrm{INH}^{-} \\
\text {treatment }\end{array}$ & Results \\
\hline 1 & $\begin{array}{l}\text { Nausea } \\
\text { Vomiting }\end{array}$ & $N A T 2^{*} 7 /{ }^{*} 7$ & Stop & Improved \\
\hline 2 & Fever & $N A T 2^{*} 6 /{ }^{*} 7$ & Substitution & Improved \\
\hline 3 & Eruption & $N A T 2^{*} 5 /{ }^{*} 7$ & Continue & $\underset{\text { histamine }}{\text { Anti- }^{-}}$ \\
\hline 4 & $\begin{array}{l}\text { Visual } \\
\text { impairment }\end{array}$ & $N A T 2^{*} \sigma /{ }^{*} \sigma$ & Dectrase & Improved \\
\hline 5 & $\begin{array}{l}\text { Peripheral } \\
\text { neuritis }\end{array}$ & $N A T 2^{*} 6 /{ }^{*} 7$ & Stop & Ease \\
\hline 6 & $\begin{array}{l}\text { Peripheral } \\
\text { neuritis }\end{array}$ & $N A T 2 * 4 /{ }^{*} 6$ & Stop & Ease \\
\hline
\end{tabular}

ることが可能となる。欧米では SA の頻度が約 50 \%と報告されているが，わが国では約 $10 \%$ と少な い. しかし現在, 結核治療や感染予防に INH は広 く用いられているため, 日本人でもその代謝酵素の ジェノタイピングは非常に重要であると言える。ま た近年, 結核患者数が増加の傾向にあるため, INH を投薬される患者はますます増加し, SA に対 する副作用防止の対策が必要となつてくるであろう.

\section{その他の臨床応用}

（1）結核患者におけるアミノグリコシド系抗生 剂による難聴回避のためのミトコンドリア DNA 遺 伝子診断 ミトコンドリア DNAの 1555 番目の Aが $\mathrm{G}$ に変異しているタイプでは, ストレプトマ イシンやゲンタマイシンなどのアミノグリコシド系 抗生剂の投与により, 不可逆的な感音性難聴になり やすいことが報告されている．この変異を有する人 の頻度は欧米人で約 200-300人に 1 人である. 日 本人においても, 約 350 人に 1 人の頻度で存在する ことが当研究室の連結不可能匿名化によるパイロッ トスタディーで示されている. よって結核患者など でストレプトマイシンを投与される患者に対して, あらかじめミトコンドリアDNA の遺伝子診断を行 うことが，それら薬剤の副作用を回避する意味で重 要である. 我々はミトコンドリアDNA1555 変異の リアルタイム検出系を構築し, 同薬剤投与予定の入 院患者に対して遺伝子診断を行っている. 現在まで に，ミトコンドリアDNA1555 変異を有している患 者は見い出されていないが, 今後も遺伝子診断を継

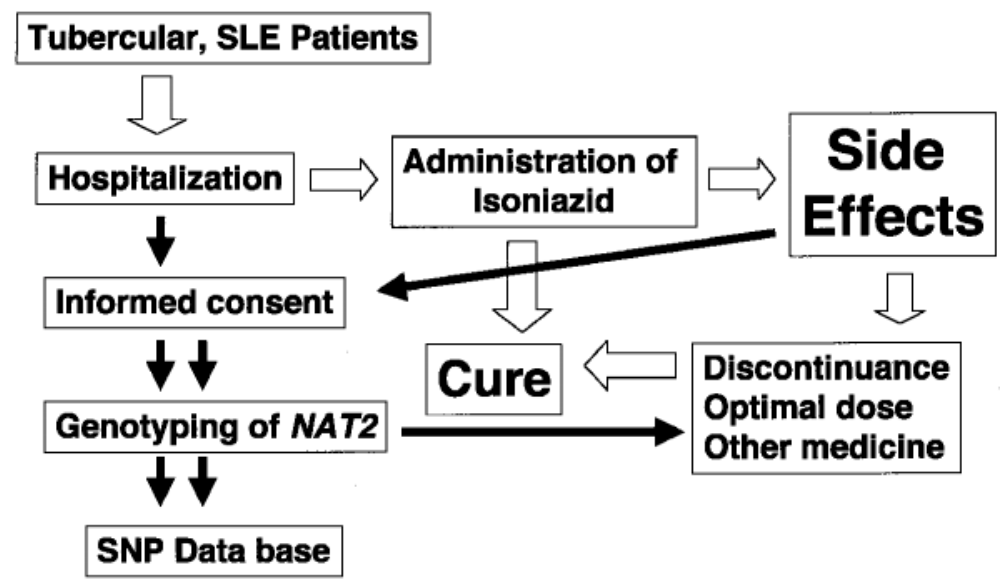

Fig. 12. Scheme of Genetic Testing in Tohoku University Hospital

東北大病院ではイソニアジドの投与が行われる結核や全身性エリテマトーデスの患者が入院すると直ちにインフォームドコンセントがなされ，NAT 2 の 遺伝子診断がなされる。これらの情報はデータベースにより管理され，イソニアジド投与後，副作用が観察され，かつ原因が NAT2 の遺伝子変異による場 合は，処方変更がなされるシステムとなっている. 
続して患者の副作用発現回避を行っていく.

（2）急性白血病患者におけるメルカプトプリン 投与による副作用発現と $\boldsymbol{T P M T}$ 遺伝子多型の解析 急性白血病患者の緩解期にメルカプトプリンが投与 されるが，同薬剤の副作用として，骨髄抑制や肝機 能障害等が発現する症例がある。この原因は様々な 因子が考えられているが，その中の 1 つとしてメル カプトプリンの代謝酵素であるチオプリン $\mathrm{S}$ 一メチ ルトランスフェラーゼ（TPMT）の SNP により， 酵素活性が減弱し, 薬物血中濃度が上昇するためで あることが示唆されている. 我々はすでに日本人集 団における TPMT のコモンミューテーションが $T P M T^{*} 3 C$ であることを見い出している. ${ }^{17,18)}$ そこ で, 実際にメルカプトプリン投与患者で副作用が発 現している症例において，TPMTの遺伝子診断を 行っている. 現在までに, 当院でメルカプトプリン の副作用を発現している患者において，TPMT*3C の存在は確認されていない. しかし,これは代謝に 影響を与える新規 SNP の存在を示唆するものであ り, 現在, 同患者の $T M P T$ 遺伝子の塩基配列を解 析中である.

（3）糖尿病患者における CYP2C9 遺伝子多型診 断による経口糖尿病薬の適正投与量の設定経口 糖尿病薬トルブタミドは $C Y P 2 C 9$ によって代謝さ れる。 日本人集団に特徵的な SNP である $C Y P 2 C 9$ *3アレルは，酵素活性の低下をまねくが，日本人 の約 25 人に 1 人はへテロ接合体である. 現在, 我 タはトルブタミド投与患者において $C Y P 2 C 9$ の遺 伝子診断を行い, 薬物血中濃度及び治療効果との相 関関係を解析している。

\section{まとめ}

近年, 遺伝子工学が加速度的に発展し, 薬剂反応 性遺伝子をはじめ数多くの遺伝子多型が検出されて いる.これらは病気の発症や投薬に対するレスポン スの差異を規定している因子であると考えられてい る. 現在, SNP 情報を利用し, 薬のレスポンダー あるいはノンレスポンダーを判断して, 患者個々に 適した処方設計がなされるテーラーメイド医療が展 開されようとしている，それらの医療を効率的に行 っていくためには, 実際の医療現場で, 患者がどの タイプの遺伝子を持つかを迅速に判定する手段がな ければならない. 最近, 遺伝子型を判定する手段と して，DNA チップが注目されている．DNA チッ
プは, 数千から数万種類の遺伝子が張り付けられて いた 0.5 一数 $\mathrm{cm}$ 角のチップであり，このチップ上 に調べたいサンプルを 1 滴たらすと遺伝子の塩基配 列の違いを迅速に判定することができる．実際に CYP のいくつかのSNP に関しては, 欧米人に特徵 的な SNP ではあるが，すでに上市されている。し かし, DNA チップは現時点で診断コストが非常に 高い. よって, まだ一般的に臨床応用することは非 常に難しく, 特別な施設のみでそれらの利用が可能 になっている。我々の構築した SNP 簡易迅速検出 システムは，その汎用性から多くの施設に導入する ことが可能であり, 即戦力として最先端医療に対応 できると考えている，将来，テーラーメイド医療が 展開され, 薬剤反応性遺伝子の SNP に由来する代 謝能力別に群を分けて, 必要最小限の薬物投与量の 設定を行えば，より安全で経済的効率の良い薬物療 法が可能になるであろう。さらに医療品開発の治験 段階であらかじめ代謝欠損者を治験対象から除外す ることにより，医薬品開発の時間やコストも大きく 減らすことができる，つまり，このような医療が展 開されることは，患者の個人的なメリットはもちろ ん, 企業のメリットも大きい. 将来的には, 外来に 通院する患者に対して，それぞれのID カードにメ モリーされている性別や血液型などの情報とともに 薬剂反応性遺伝子の SNP 情報も記憶され, 有効利 用されることが期待される.

謝辞本研究を遂行するにあたり, 終始御指導 御鞭撻を賜りました水柿道直東北大学医学部附属病 院教授・薬剂部長に深謝いたします。本研究は東北 大学医学部附属病院薬剤部で行われたものであり, ご協力いただきました大学院生や薬剤師の先生をは じめとする共同研究者の方々と検体の提供をいただ きました多くの方々に心より感謝いたします．な お, 本研究の一部は創薬等ヒューマンサイエンス総 合研究事業の補助金によって行われたものであり, 併せて感謝の意を表します。

\section{REFERENCES}

1) http://www.imm.ki.se/CYPalleles/default.htm.

2) Furuta T., Ohashi K., Kamata T., Takashima M., Kosuge K., Kawasaki T., Hanai H., Kubota T., Ishizaki T., Kaneko E., Ann. In- 
ter. Med., 129, 1027-1030 (1998).

3) Furuta T., Shirai N., Takashima M., Xiao F., Hanai H., Nakagawa K., Sugimura H., Ohashi K., Ishizaki T., Pharmacogenetics, 11, 341-348 (2001).

4) Ingelman-Sundberg M., J. Inter. Med., 250, 186-200 (2001).

5) Prezant TR., Agapian JV., Bohlman MC., Bu X., Oztas S., Qiu WQ., Arnos KS., Cortopassi GA, Jaber L., Rotter JI., Shohat M., FiscelGhodsian N., Nature Genet., 4, 289-294 (1993).

6) Matsubara Y., Fujii K., Rinaldo P., Narisawa K., Acta Paediatrica, 88, 65-68 (1999) .

7) Mizugaki M., Hiratsuka M., Agatsuma Y., Matsubara Y., Fujii K., Kure S., Narisawa K., J. Pharm. Pharmacol., 52, 199-205 (2000).

8) Hiratsuka M., Agatsuma Y., Omori F., Narahara K., Inoue T., Kishikawa Y., Mizugaki M., Biol. Pharm. Bull., 23, 1131-1135 (2000).

9) Hamdy S. I., Hiratsuka M., Narahara K., ElEnany M., Moursi N., Ahmed MS-E., Mizugaki M., Br. J. Clin. Pharmacol. in press.

10) Hamdy S. I., Hiratsuka M., Narahara K., ElEnany M., Moursi N., Ahmed MS-E.,
Mizugaki M., Eur. J. Clin. Pharmacol. in press.

11) Hiratsuka M., Agatsuma Y., Mizugaki M., Mol. Genet. Metab., 68, 357-362 (1999) .

12) Hiratsuka M., Narahara K., Hamdy S. I., Endo N., Kishikawa Y., Agatsuma Y., Matsuura M., Inoue T., Tomioka Y., Mizugaki M., Clin. Biochem. in press.

13) Schutz E., von Ahsen N., Oellerich M., Clin. Chem., 46, 1728-1737 (2000).

14) Blomeke B., Sieben S., Spotter D., Landt O., Merk H. F., Anal. Biochem., 275, 93-97 (1999).

15) Schur B. C., Bjerke J., Nuwayhid N., Wong, S. H., Clin. Chim. Acta, 308, 25-31 (2001).

16) Hiratsuka M., Kishikawa Y., Narahara K., Inoue T., Hamdy S. I., Agatsuma Y., Tomioka Y., Mizugaki M., Anal. Biochem., 289, 300 -303 (2001).

17) Hiratsuka M, Inoue T., Omori F., Agatsuma Y., Mizugaki M., Mutat. Res. Fundam. Mol. Mech. Mutagen., 448, 91-95 (2000) .

18) Hiratsuka $M$, Inoue T., Omori F., Agatsuma Y., Mizugaki M., Biol. Pharm. Bull., 23, 1090 -1093 (2000). 